İş ve İnsan Dergisi I The Journal of Human and Work

Y1l | Year: Nisan | April 2018

Cilt-Sayı | Volume-Issue: 5 (1)

ss I pp: $33-46$

doi: 10.18394/iid.348499

e-ISSN 2148-967X

http://dergipark.gov.tr/iid/

Araştırma Makalesi

\title{
İstihdam Şekillerine Göre Örgütsel Adalet Algılaması: Üniversite Hastanesi Örneği
}

\author{
Organizational Justice Perception by Types of Employment: A Case of University \\ Hospital
}

\author{
Ferda Alper Ay a , Özgün Ünal *, b, Mustafa Amarat *, c, Sümeyye Hekim *, d
}

MAKALE BİLGİSI

Anahtar Kelimeler:

Örgütsel Adalet, Ișlemsel

Adalet, Dağıtımsal Adalet,

Etkileşimsel Adalet, İstihdam

Şekli

Tarihler :

Geliş 01 Kasım 2017

Düzeltme geliș 13 Aralık

2017

Kabul 21 Aralık 2017
ÖZ

Çalışmanın amacı, hastane çalışanlarının istihdam şekillerine göre örgütsel adalet algılamalarında farklılık olup olmadığını belirlemektir. Bunun yanında çalışanların sosyodemografik özelliklerinin örgütsel adalet algllamalarında farklılık oluşturup oluşturmadığının belirlenmesi de hedeflenmektedir. Çalışmanın evrenini Sakarya Üniversitesi Eğitim Araştırma Hastanesi'nde çalışan 3055 sağlık personeli oluşturmaktadır. Çalışmanın örneklemi 405 kişidir. Veri toplama aracı olarak sosyo demografik özellikleri belirlemeye yönelik bir form ile Colquitt (2001) tarafindan geliştirilen Örgütsel Adalet Algısı ölçeği kullanılmıştır. Verilerin analizinde; tanımlayıcı istatistiksel metotlar, korelasyon analizi, bağımsız örneklemlerde t-testi ve ANOVA analizlerinden yararlanılmıştır. Çalışmanın bulgularına göre devlet memurlarının örgütsel adalet algısı ortalamaları 3,27; sözleşmeli çalışanların 2,82; taşeron işçilerin ise 2,99'dır. Yapılan analiz sonucunda memurlar, sözleşmeli çalışanlar ve taşeron işçilerin örgütsel adalet algıları arasında anlamlı bir farklılık bulunmuştur. Ayrıca çalışanların yaşları, eğitim durumları, aylık ortalama gelirleri ve idari görevleri örgütsel adalet algllarında anlamlı farklılık oluşturmaktadır. Ancak cinsiyet, medeni durum ve mesleki tecrübe anlamlı bir farklılık oluşturmamaktadir.

\section{ARTICLE INFO}

\section{Keywords:}

Organizational Justice,

Procedural Justice,

Distributive Justice,

Interactional Justice, Types

of Employment

Article history:

Received 01 November 2017

Received in revised form 13

December 2017

Accepted 21 December 2017

\begin{abstract}
A B S T R ACT
The aim of the study is to determine following questions: Do the types of employment of the participants make a difference in perceptions of organizational justice? Do the sociodemographic features of the participants make a difference in perceptions of organizational justice? The population of the study is 3055 employees, of which Sakarya University Training and Research Hospital. The sample of the study is 405 employees. As a data collection tool a question form for determining socio-demographic characteristics and the Organizational Justice Perception scale developed by Colquitt (2001) were used. In the analysis of the data, descriptive statistical methods, correlation analysis, independent samples t-test and ANOVA analyses were used. According to the findings of the study, the average of perception of organizational justice of civil servants is 3.296; contracted workers average is 2.823 of; subcontracted workers average is 2.996. According to another finding of the study, a significant difference was found between the perceptions of organizational justice of civil servants, contracted workers and subcontracted workers. In addition, the age, educational status, monthly average income and administrative duties of the employees are significantly different in terms of organizational justice perceptions. However, gender, marital status and professional experience do not make any significant difference.
\end{abstract}

\footnotetext{
a Yrd. Doç. Dr., Cumhuriyet Üniversitesi, Sağllk Bilimleri Fakültesi, Sağlı Yönetimi Bölümü. Sivas, Türkiye. E-mail: ferdaalperay@hotmail.com. ORCID: 0000-0002-6170-1578 *,b İletissim kurulacak yazar, Arş. Gör., Sakarya Üniversitesi, İşletme Fakültesi, Sağlı Yönetimi Bölümü. Sakarya, Türkiye. E-mail: ozgununal@ sakarya.edu.tr. ORCID: 0000-0002$1245-2456$

*,c Arş. Gör., Sakarya Üniversitesi, İsletme Fakültesi, Sağlı Yönetimi Bölümü. Sakarya, Türkiye. E-mail: mustafaamarat@ sakarya.edu.tr. ORCID: 0000-0001-8954-6314 *,d Tezli Yüksek Lisans Ögrencisi, Sakarya Üniversitesi, Sosyal Bilimler Enstitüsü, Sağllk Yönetimi EABD, Sakarya, Türkiye. E-mail: sumeyyehekim@ @otmail.com. ORCID: 00000002-6762-4294
} 


\section{GİRiş}

Örgütler, ortak bir amacı olan insanların bir araya geldiği, kendine ait kaynakları ve kendine ilişkin kuralları, prosedürleri, inançları ve normları olan yapılardır (Baş, Ünal, Amarat \& Sağlık, 2017: 21). İster kamu kurumları ister özel kurumlar olsun örgütlerin başarısında beşerî faktörler son derece önemli rol oynamaktadır. Sağlık hizmetlerinin emek yoğun bir hizmet türü olması ve sağlık hizmetlerinin hata götürmeyen yapısı nedeniyle sağlık hizmeti sunan kuruluşların sahip oldukları beşerî faktörler son derece önemlidir.

Türkiye'de son dönemde "yeni kamu yönetimi" anlayışının benimsendiği görülmektedir. Bu anlayış kamu kurumlarının örgütlenme biçimleri ve personelin istihdam biçimleri gibi konularda değişiklikleri beraberinde getirmektedir (Batchelder \& Alexander, 2009: 153). Türkiye'de sağlık alanı yeni kamu yönetimi uygulamalarının ilk olarak görüldüğü alanlardan birisi olma özelliğini barındırmaktadır (Sayan \& Küçük, 2012: 173). Bu uygulamalara örnek olarak 2003 yilında Sağlikta Dönüşüm Programı (SDP) ile beraber sağlık personelinin istihdamında yaşanan değişiklikler gösterilebilir. Program kapsamında Sağlık Bakanlığı "planlama ve denetleme" rollerini üstlenerek sözleşme ve hizmet alımı uygulamaların başlatmıştır (Akdağ, 2007: 17). Böylece sağlık kurumları üçüncü kişilerle yapılan sözleşmeler ile "taşeron personel" çalıştırabilmektedir. Sağlık personeli 2003 yılına kadar ağılıklı olarak 657 sayılı Devlet Memurları Kanunu kapsamında "memur" olarak istihdam edilmekteyken, 2003 yılında hayata geçen SDP ile birlikte dört farklı şekilde istihdam edilmeye başlanmıştır (Sayan \& Küçük, 2012: 173). Memur statüsünde çalışmayan personel sırası ile (1) sözleşmeli personel, (2) taşeron personel, (3) vekil ebe ve hemşire ve (4) yabancı sağlık personelidir. Sağlık Bakanlığında çalışan kadrolu ve hizmet alımı ile çalışan personelin sayıları Tablo-1'de verilmiştir. Buna göre 2012 yllında diğer personel ve hizmet alımı sayısı 209.736 iken bu sayı yıllar içerisinde 112.216 (\%53) artış göstererek 2016 yılında 321.952 sayısına ulaşmıştır. Burada önemli olan asıl gösterge diğer personel ve hizmet alımlarının toplam sağlık personeli içerisindeki payıdır. 2012 yilında bu statüye sahip personelin toplam personele oran $1 \%$ 30,02 iken 2016 y1l yılinda \%36,94 olmuştur. (Bkz. Tablo 1)

Sağlık sektöründe bu şekilde parçalı olarak istihdam biçimlerinin var olması personel arasında örgütsel adalet algılarında farklılıklara sebep olacağı düşünülmektedir. $\mathrm{Bu}$ çalışmanın amacı, hastane çalışanlarının istihdam şekillerine göre örgütsel adalet algılamalarında farklılık olup olmadığını belirlemektir. Bunun yanında çalışanların sosyodemografik özelliklerinin örgütsel adalet algılamalarında farklılık oluşturup oluşturmadığının belirlenmesi de hedeflenmektedir.

\section{KURAMSAL CERÇEVE VE HIPOTEZLER}

\section{1. Örgütsel Adalet Algısı}

Örgütsel adalet kavramı en yalın hali ile örgütlerde dağıtım, işlem ve etkileşimin adil ve hakkaniyetli olarak yapılması olarak tanımlanabilir (İyigün, 2012: 50-51). Örgütsel adaletle ilgili başlangıçtaki çalışmalar, dağıtım adaleti terimine odaklanmaktadır (Colquitt, 2001: 386). Sosyal psikologlar tarafindan incelenen ilk adalet yapısı dağııım adaleti, Adams'ın (1965) çalışmaları üzerine inşa edildiği görülmektedir (Nowakowski \& Conlon 2005: 5). Örgütsel adalet sadece dağıtımlarda ya da dağıtımların uygulanmasında olmamakta, bununla beraber örgütteki kuralların uygulanması biçiminde ve bireyler arasındaki etkileşimde de yer almaktadır (Barling \& Phillips 1993: 650). Bireylerin örgütlerdeki adalet algısını tanımlamak için ortaya konulan bir kavram olan örgütsel adalet, genel olarak dağıtımsal adalet, işlemsel (veya prosedürel) adalet ve etkileşimsel adalet olmak üzere üç boyutta incelenmektedir (Aykanat \& Yildırım, 2012: 164).

1. Dağıtımsal Adalet, örgütün kaynaklarının

Tablo 1: Sağlık Bakanlığı Personel Sayısındaki Değị̧im

\begin{tabular}{cccccc}
\hline & $\mathbf{2 0 1 2}$ & $\mathbf{2 0 1 3}$ & $\mathbf{2 0 1 4}$ & $\mathbf{2 0 1 5}$ & $\mathbf{2 0 1 6}$ \\
\hline Kadrolu & $\mathbf{4 8 8 . 7 8 2}$ & 510.541 & 530.697 & 545.455 & 549.382 \\
Diğer Personel ve Hizmet Alımı & 209.736 & 224.618 & 229.625 & 241.897 & 321.952 \\
Toplam & 698.518 & 732.323 & 749.584 & 787.352 & 871.334 \\
\hline
\end{tabular}

Kaynak: Sağlık istatistikleri ylllığı 2015, Sağ lık istatistikleri ylllğ̣̆ 2016. 
ve kazanımlarının dağıtımında adalet ve hakkaniyetli olmayla ilgilidir (Tutar, 2007: 99). Dağıtım adaleti, bir kişinin sosyal değişim veya etkileşimden aldığ sonuçların algılanan adaleti olarak tanımlanabilir. Çalışanlar adaleti, ilk olarak algıladıkları katkılarını, ya da onların aldıkları çıktıya göre girdilerini değerlendirirler. Daha sonra onların aldıkları çıktıların adil olup olmadığını diğer çalışanlar ile ya da standartlarla karşılaştırırlar (Nowakowski \& Conlon 2005: 5).

2. Işlemsel Adalet, yöneticilerin dağıtım kararlarını (ücret, terfi, performans değerlemesi vb.) alma biçiminde çalışanlarca adil olarak algılamasını içermektedir (İçerli, 2010: 81). İşlemsel (prosedürel) adalet, dağıtımdan ziyade bu dağıtımın ne şekilde gerçekleştirildiği sorununu konu almaktadır. İşlemsel adalet algılaması çalışanlar üzerinde derin etkiler bıraktığından örgütler için önemli sonuçları bulunmaktadır (İyigün, 2012: 58).

3. Etkileşimsel Adalet, yöneticiler ile çalışanlar arasındaki iletişimin adalet algılamasını vurgulamaktadır. Başka bir deyişle yöneticilerin dağıtım kararlarının alınmasına yönelik kullanılan yöntemleri şeffaf bir biçimde çalışanlara açıklamasıdır. Etkileşimsel adaletin özünü çalışanlara değer verme ve saygilı davranma oluşturmaktadır (Cohen-Charash \& Spector, 2001: 281). Etkileşimsel adalet, işgörenlerin, işlemlerin uygulanması sürecinde kendileriyle iletişimin samimiyet ve saygıya dayanması gibi normatif beklentileri içerir (Büyükyılmaz \& Ay, 2017: 213; Polat \& Celep, 2008: 309).

\section{2. Çalışmanın Hipotezleri}

İstihdam şekline göre farklı çalışanlar, aynı mesleki yeterliliklere sahip olmalarına ve aynı iş kolunda çalışmalarına rağmen, kadrolu çalışanlara nazaran, başta iş güvenliği olmak üzere terfi, tayin, sosyal yardımlar ve yasal güvenceler bakımından bir takım eksik haklara sahiptirler (Kalay, Arslan \& Oflas, 2013: 118). Literatürde istihdam şekillerine göre oluşan farklılıklara ilişkin çalışmalar var olsa da bu konu nezdinde çalışmaların sınırlı kaldığı, bu çalışmaların genellikle kısmi zamanlı ve tam zamanlı personel arasındaki farklılıklara yönelik olduğu ve bu farklılı̆̆ 1 açıklamak için araştırmacıların "Referans Çerçeve Teorisi"ni kullandıkları görülmektedir (Omar, 2010: 148). Referans Çerçeve Teorisi esasen Adams'ın eşitlik teorisine dayanmaktadır (Thorsteinson, 2003: 152).
Eşitlik teorisi; çalışanların elde ettikleri kazanımlar ile bu kazanımları elde etmek için gösterdikleri çabayı bir başka çalışanınki ile karşılaştırdıklarında bir farklilik algilarlarsa bu durumun memnuniyetsizlik yaratacağını ifade etmektedir (Adams, 1965). Referans Çerçeve Teorisi, objektif ve çevresel özelliklerin ve olayların, bu çevre hakkındaki alg1 ve kararlardan geçtiği bir filtreleme süreci olarak tanımlanmaktadır (Miller \& Terborg, 1978). Bireylerin algısal referans noktasını, geçmiş tecrübeleri, sosyal karşılaştırma süreçleri ve mevcut ve gelecekteki alternatifler oluşturmaktadır. $\mathrm{Bu}$ teori doğrultusunda statüleri farklı olan çalışanların işe ilişkin bakış açıları belirgin şekilde farklıdır. Bu farklılığın temel nedeni farklı statüdeki çalışanların kendilerine karşılaștırmak için referans aldıkları grupların farklı olmasıdır. Kısmi zamanlı çalışanlar kendilerine tam zamanlı çalışanları referans grubu olarak aldıklarında haklarının onlara kıyasla daha sınırlı olduğunu düşünecek ve tatminsizlik yaşayacaklardır (Thorsteinson, 2003: 153).

Özet olarak Referans çerçevesi Teorisine göre statüsü farklı personelin örgüt içinde yapabileceği işin özellikleri ve örgütün sosyal sistemine dâhil olma dereceleri farklı olacaktır. Bunun yanında farklı statüdeki personelin kazanımları da birbirinden farklı olacaktır. $\mathrm{Bu}$ nedenle statü farklılıkları muhtemelen personelin işe ilişkin görüşlerini de etkileyecektir (Eberhardt \& Shani, 1948: 893). Bu bilgiler 1şığında kısmi zamanlı ve tam zamanlı çalışanlar arasında ki işe ilişkin farklılıkların memur, sözleşmeli personel ve taşeron işçiler gibi farklı statüde çalışan personel için de geçerli olacağı düşünülmektedir. Çünkü farklı statüde çalışan personelin özlük ve yan hakları arasında farklılıklar mevcuttur. Bu farklılıklar personelin kazanım-çaba karşılaştırmasını yaparken referans aldıkları grubun özlük ve yan haklarını dikkate aldıklarında tatminsizlik meydana getirebileceği düşünülmektedir. Daha öncede değinildiği gibi Referans Çerçeve Teorisinde grupların sosyal algılamalarında referans aldıkları gruplara göre farklı sonuçlar elde edebileceği ifade edilmektedir.

Sağlık personellinin statülerine ilişkin yapılan çalışmalarda farklılıklara rastlamak mümkündür. Örneğin, Kalay, Arslan ve Oflas (2013: 117-118) araştırmalarında, memur ve sözleşmeli sağlık personelinin iş doyumu düzeyleri arasında farklılıklar olduğunu saptamıştır. Araştırmalarında memurların iş doyumlarının, sözleşmeli sağlık personelinin iş doyumlarına göre istatistiksel olarak anlamlı bir şekilde daha yüksek olduğu saptanmıştır. Karahan (2008: 239), kadrolu ve sözleşmeli hemşirelerin örgütsel bağlılıkları arasında anlamlı farklılıklar olduğunu tespit etmiştir. Araştırma bulgularında kadrolu 
hemşirelerin sözleşmelilere göre daha çok örgüte bağlı olduklarını belirtmiştir. Benzer bir şekilde Savgun Doğruöz (2009: 78) kadrolu ve kadrosuz öğretmenlerin örgütsel bağlılıkları arasında anlamlı farklılık bulmuştur. Sağlık sektöründe yapılan bir araştırmada istihdam şekilleri ile iş memnuniyeti arasındaki anlamlı bir fark tespit edilmemiştir (Ünalan vd., 2006:9). Kısacası, ampirik çalışmaların az olması nedeniyle bu teorik çalışmaların, farklı statüdeki çalışanların tutum ve davranışlarının anlaşılmasına çok az katkı sağladığı görülmektedir (Conway \& Briner, 2002: 280-281).

Özet olarak, memurlar ile memur statüsünde çalışmayan personelin tutum ve davranışları konusunda farklılıkların olduğu varsayımını destekleyecek çalışmalar literatürde mevcuttur. Kadro farklılığıyla birlikte çalışanların işe ilişkin tutumlarını etkileyebilecek başka değişkenlerde mevcuttur. Başar'a (2011) göre, personelin dağıtımsal, işlemsel ve etkileşimsel adalet algılamaları çalışanların davranışlarını ve tutumlarını belirleyen önemli bir faktördür. Literatürde örgütsel adaletin iş tatminine (Yıldırım, 2007: 253), sanal kaytarmaya (Alper Ay, Demirel \& Erbaş, 2017; Kaplan \& Öğ̈̈t, 2012: 1), örgütsel bağlılığa (Cihangiroğlu, 2011: 9; Iş1k, Uğurluoğlu \& Akbolat, 2012: 254; Tutar, 2007: 97) ve problem çözme becerisine (Çetin, Basım \& Karataş, 2011: 71) etkisi olduğu tespit edilmiştir. Sağlık sektöründe daha önce yapılan çalışmalarda Akbolat ve Işık (2008: 250) çalışanların istihdam biçimlerinin tükenmişlik düzeyine etkisinin olduğunu, Karahan (2008: 241) çalışanların istihdam biçimlerinin örgütsel bağlılıklarında farklılık oluşturduğunu belirtmektedir. Bunun yanı sıra Işık ve arkadaşları (2012: 254) örgütsel adalet algısının örgütsel bağlılı̆̆1 etkilediğini, Balaban ve Konyalı (2016: 197) örgütsel adalet algısı ile tükenmişlik arasında negatif yönlü bir ilişki olduğunu ve Keklik ve Coşkun Us (2013: 143) örgütsel adalet algısının iş tatminini etkilediğini ortaya koymuştur. $\mathrm{Bu}$ sebeplerden dolayı sayısı giderek artan memur statüsünde çalışmayan personel ile memurların örgütsel adalet anlayışları arasındaki farkların belirlenmesi oldukça önemlidir. $\mathrm{Bu}$ noktadan hareketle aşağıdaki hipotez geliştirilmiştir.

Hipotez 1: İstihdam şekline göre örgütsel adalet algısında anlamlı farklılık vardır.

Sağlık personellerinin tutum ve davranışlarında oluşan farklılıkları sadece örgütsel adalet algılamaları ile ilişkili olmadığı literatürde personellerin örgütsel adalet algılamalarında sosyodemografik özelliklerine göre de farkl1ların tespit edildiği görülmektedir (Durmuş, 2015: 65; Kalay vd., 2013: 117; Özk1lıçc1, 2011: 115; Yalçın, 2011:
141). Bu noktadan hareketle aşağıdaki hipotezler geliştirilmiştir.

Hipotez 2: Yaş örgütsel adalet algısında anlamlı farklılık oluşturmaktadır.

Hipotez 3: Eğitim durumu örgütsel adalet algısında anlamlı farklılık oluşturmaktadır.

Hipotez 4: Gelir durumu örgütsel adalet algısında anlamlı farklılık oluşturmaktadır.

Hipotez 5: İdari görev olup olmaması örgütsel adalet algısında anlamlı farklılık oluşturmaktadır.

Hipotez 6: Cinsiyet örgütsel adalet algısında anlamlı farklılık oluşturmaktadır.

Hipotez 7: Medeni durum örgütsel adalet algısında anlamlı farklılık oluşturmaktadır.

Hipotez 8: Mesleki tecrübe örgütsel adalet algısında anlamlı farklılık oluşturmaktadır.

\section{YÖNTEM}

Çalışmanın evrenini 3055 çalışanın oluşturduğu Sakarya Üniversitesi Eğitim Araştırma Hastanesi oluşturmaktadır. Anket uygulaması yapılmadan önce olasılıklı örnekleme yöntemlerinden tabakalı rast gele örnekleme yöntemi ile örneklem büyüklüğü 342 olarak belirlenmiştir (Özen \& Gül, 2007: 404). Ancak çalışmada belirlenen örneklem sayısından daha fazla katılımcıya ulaşılmış olup 405 kişilik bir örneklem grubu çalışmaya dâhil olmuştur. Çalışmanın alan uygulaması 1 Şubat 2017 - 24 Mart 2017 tarihleri arasında yapılmıştır.

Araştırmada veri toplama aracı olarak katılımcıların sosyo-demografik özelliklerini belirlemeye yönelik 8 sorudan oluşan bir form ile Colquitt (2001) tarafından geliştirilen ve Özmen, Arbak ve Özer (2007) tarafindan Türkçeye uyarlanan Örgütsel Adalet Algısı ölçeği kullanılmıştır. Örgütsel adalet algısı ölçeği 3 boyut (işlemsel adalet, dağıtımsal adalet, etkileşimsel adalet) ve 20 sorudan oluşmaktadır. Sorular, 5'li Likert tipinde “(5) Kesinlikle Katılıyorum, (4) Katılıyorum, (3) Fikrim Yok, (2) Katılmiyorum ve (1) Kesinlikle Katılmıyorum" olarak düzenlenmiştir.

Araştırmada elde edilen verilerin analizinde SPSS 22 ve AMOS 22 paket programları kullanılmış olup; tanımlayıcı istatistiksel metotlar, korelasyon analizi, iki ortalama arasındaki farkın önem kontrolü ve ANOVA testlerinden yararlanılmıştır. Sonuçlar \%95'lik güven aralığında, $\mathrm{p}<0,05$ anlamlılık düzeyinde değerlendirilmiştir. 


\subsection{Etik Uygunluk ve Gerekli İzinler}

Çalışmanın anket uygulaması yapılmadan önce Cumhuriyet Üniversitesi Girişimsel olmayan Klinik Araştırmaları Etik kurulundan 2015-10/16 nolu etik kurul uygunluk kararı ve anketin uygulanması için Sakarya İli Kamu Hastaneler Birliği Genel Sekreterliğinden 23916764-702.99-237 sayılı izin alınmıştır.

\section{BULGULAR}

Örgütsel Adalet ölçeğinin geçerlilik ve güvenirliğini test etmek amac1 ile Cronbach Alpha katsayıs1, keşfedici faktör analizi (KFA) ve doğrulayıcı faktör analizi (DFA) kullanılmıştır. Colquitt (2001) tarafından örgütsel adalet ölçeğinin Cronbach Alpha kat sayıları; işlemsel adalet boyutu için 0,780, dağıtımsal adalet boyutu için 0,920 ve etkileşimsel adalet boyutu için 0,790 olarak saptanmıștır. Çalışmamızda ise ölçeğin güvenilirlik analizi sonucuna göre (Tablo 2) Cronbach Alpha değeri örgütsel adalet algısı için 0,930 , işlemsel adalet boyutu için 0,863 , dağıtımsal adalet boyutu için 0,874 ve etkileşimsel adalet boyutu için 0,953 olarak hesaplanmıştır. Bulunan bu sonuçlar ölçeğin güvenilirliğinin yüksek olduğunu göstermektedir (Bkz. Tablo:2).

Örgütsel adalet ölçeğine ilişkin yapılan analizler sonucunda ölçek KMO (Kaiser-Meyer-Olkin) değeri 0,929 olarak bulunmuş olup BTS (Bartlett Test Sonucu) sonucu anlamlıdır. $\mathrm{Bu}$ sonuçlar verilerin faktör analizi için uygun olduğunu göstermektedir. Ölçek KFA (Keşfedici Faktör Analizi) sonucunda orijinal ölçek ve Türkçe geçerlilik güvenilirlik çalışmalarında olduğu gibi 3 alt boyuta ayrılmıştır. Ancak çalışmada 15. soru iki farklı boyuta dağıldığı için çalışma kapsamından çıkartılmıştır. Bu doğrultuda araştırmada kullanılan

Tablo 2: Güvenilirlik Analizi Sonuçları

\begin{tabular}{cc}
\hline İşlevsel Adalet & 0,863 \\
Dağıtımsal Adalet & 0,874 \\
Etkileşimsel Adalet & 0,953 \\
Örgütsel Adalet Algısı & 0,930 \\
\hline
\end{tabular}

Tablo 3: Keģfedici Faktōr Analizi Sonuçlan

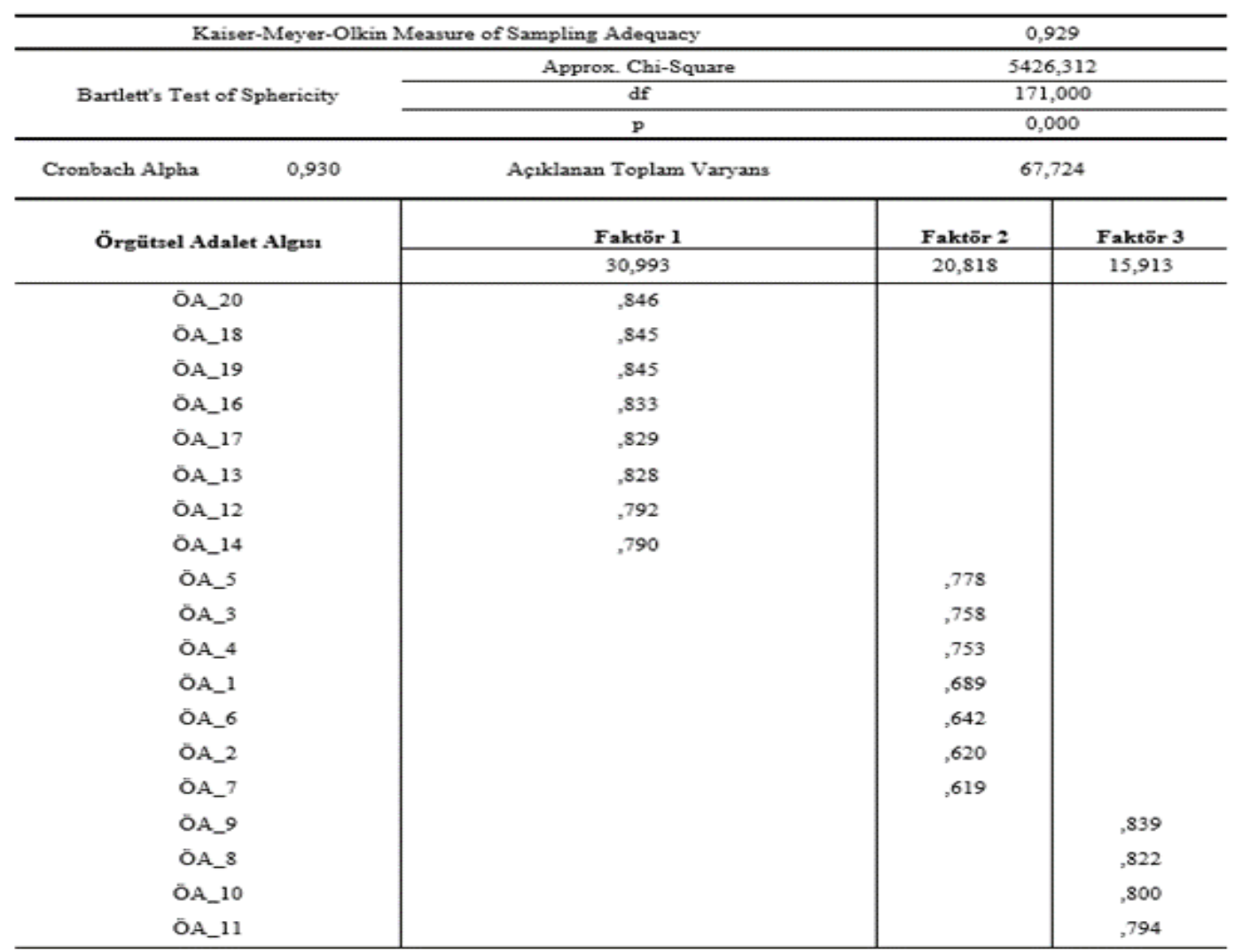


ölçeğin soru sayısı işlemsel adalet boyutu için 7 soru, dağıtımsal adalet boyutu için 4 soru ve etkileşimsel adalet boyutu için 8 soru olmak üzere toplamda 19 olmuştur. 3 boyut halinde ölçeğin açıklanan toplam varyansı $\% 67,724$ ' tür. Toplam varyans içinde faktörlerin açıklanan varyansları ve faktör yükleri Tablo 3'de görülmektedir.

KFA sonucunda 3 boyuta toplanan ölçeğe uygulanan DFA (Doğrulayıcı Faktör Analizi) sonucunda ölçeğin uyum iyiliklerinin kabul

edilebilir sınırlar içerisinde olduğu görülmüştür. DFA sonuçları ve kabul edilebilir uyum iyilikleri Tablo 4'te görülmektedir.

Tablo 5'te çalışmaya katılan katılımcıların demografik bilgileri yer almaktadır. Buna göre katılımciların \%69,4'ü kadın, \%30,6'sı erkektir; \%64,7'si evli, \%35,3'ü bekârdır; \%30,9'u devlet memuru, \%5,2'si sözleşmeli çalışan, \%63,5'i

Tablo 4: Uyum İyilikleri ve Kabul Aralığ

\begin{tabular}{cccc}
\hline Uyum Ölçütleri & Iyi Uyum & Kabul Edilebilir Uyum & Ö.A. \\
\hline $\mathrm{X}^{2} / \mathrm{sd}$ & $0 \leq \mathrm{X}^{2} / \mathrm{sd} \leq 2$ & $2 \leq \mathrm{X}^{2} / \mathrm{sd} \leq 4$ & 2,570 \\
RMSEA & $0<\mathrm{RMSEA}<0,05$ & $0,05 \leq \mathrm{RMSEA} \leq 0,08$ & 0,062 \\
NFI & $0,95 \leq \mathrm{NFI} \leq 1$ & $0,90 \leq \mathrm{NFI} \leq 0,95$ & 0,933 \\
CFI & $0,97 \leq \mathrm{CFI} \leq 1$ & $0,95 \leq \mathrm{CFI} \leq 0,97$ & 0,958 \\
GFI & $0,95 \leq \mathrm{GFI} \leq 1$ & $0,90 \leq \mathrm{GFI} \leq 0,95$ & 0,909 \\
AGFI & $0,90 \leq \mathrm{AGFI} \leq 1$ & $0,85 \leq \mathrm{AGFI} \leq 0,90$ & 0,880 \\
\hline
\end{tabular}

Kaynak: Tezcan, 2008: 43; Meydan ve Șeșen, 2015: 37

Tablo 5: Demografik Deǧiskenler

\begin{tabular}{|c|c|c|c|}
\hline Demografik Değişken & & $\mathbf{N}$ & $\%$ \\
\hline \multirow{2}{*}{ Cinsiyet } & Kadin & 281 & 69,4 \\
\hline & Erkek: & 124 & 30,6 \\
\hline \multirow{2}{*}{ Medeni Durum } & Evli & 262 & 64,7 \\
\hline & Bekâr & 143 & 35,3 \\
\hline \multirow{3}{*}{ İstihdam Şekli (Kadro Durumu) } & Devlet Memurlan & 125 & 30,9 \\
\hline & Sözlesmeli Çalışanlar & 21 & 5,2 \\
\hline & Taseron Isçi & 257 & 63,5 \\
\hline \multirow{2}{*}{ İdari Görev } & Evet & 50 & 12,3 \\
\hline & Hayr & 347 & $\$ 5,7$ \\
\hline \multirow{4}{*}{ Gelir Durumu } & Asgari Ücret & 85 & 21,0 \\
\hline & $1500-1999$ & 84 & 20,7 \\
\hline & $2000-2999$ & 88 & 21,7 \\
\hline & $\geq 3000$ & 96 & 23,7 \\
\hline \multirow{3}{*}{ Kurumda Çalışma Süresi } & 5 Yil Alt & 173 & 42,7 \\
\hline & $5-10 \mathrm{Y}_{11}$ & 127 & 31,4 \\
\hline & 10 Yal Ûstū & 79 & 19,5 \\
\hline \multirow{5}{*}{ Yaş } & $\leq 25$ Yas & 87 & 21,5 \\
\hline & 25-29 Yas & 118 & 29,1 \\
\hline & 30-34 Yas & 80 & 19,8 \\
\hline & 35-39 Yas & 61 & 15,1 \\
\hline & $\geq 40 \mathrm{Yas}$ & 59 & 14,6 \\
\hline \multirow{5}{*}{ Eggitim Durumu } & inkögretim & 27 & 6,7 \\
\hline & Lise & 119 & 29,4 \\
\hline & Ōn lisans & 125 & 30,9 \\
\hline & Lisans & 112 & 27,7 \\
\hline & Lisansüstū & 22 & 5,4 \\
\hline
\end{tabular}


taşeron işçidir, \%12,3'ünün idari görevi vardır; $\% 23,7$ 'sinin 3000 lira ve üzeri aylık gelir durumuna sahiptir; \%42,7'si, 5 y1ldan az, \%31,4'ü 5 y1l ila 10 yıl arasında, \%19,5'i ise 10 yıldan fazla süredir kurumda çalışmaktadır. Katılımcıların çoğunluğunun (\%29,1'inin) 25-29 yaş arasında bireylerden oluştuğu ve büyük kısmının ön lisans $(\% 30,9)$ veya lisans mezunu $(\% 27,7)$ olduğu görülmektedir.

Tablo 6 'da katılımcıların istihdam şekillerine göre örgütsel adalet algısı ortalamaları ve örgütsel adaletin alt boyutlarının ortalamaları görülmektedir.
Buna göre örgütsel adalet algısı ortalaması en yüksek olan kadro grubunu devlet memurları $(3,296 \pm 0,658)$ oluştururken en düşük grubu sözleşmeli personel $(2,823 \pm 0,877)$ oluşturmaktadır.

Ortalamalara göre örgütsel adaletin etkileşimsel adalet boyutunun diğer boyutlara göre daha yüksek olduğu görülmektedir. Etkileşimsel adalet boyutunda bu ortalamalar devlet memurları için $3,427( \pm 0,830)$, sözleşmeli personel için 2,977 $( \pm 1,154)$ ve taşeron işçi için $3,308( \pm 1,125)$ olarak saptanmıştır.

Tablo 6: İstihdam Şekillerine Göre Örgütsel Adalet Algısı Ortalamaları

\begin{tabular}{|c|c|c|c|}
\hline Kadro Durumu & & Ort. & S.S. \\
\hline \multirow{5}{*}{ Devlet Memurları } & İşlevsel Adalet & 3,306 & 0,804 \\
\hline & Dağıtımsal Adalet & 3,016 & 1,081 \\
\hline & & & \\
\hline & Etkileşimsel Adalet & 3,427 & 0,830 \\
\hline & Örgütsel Adalet Algısı & 3,296 & 0,658 \\
\hline \multirow{5}{*}{ Sözleşmeli Çalışanlar } & İşlevsel Adalet & 2,669 & 0,874 \\
\hline & Dağıtımsal Adalet & 2,784 & 0,853 \\
\hline & & & \\
\hline & Etkileşimsel Adalet & 2,977 & 1,154 \\
\hline & Örgütsel Adalet Algısı & 2,823 & 0,877 \\
\hline \multirow{5}{*}{ Taşeron Iş̧̧i } & İ̧levsel Adalet & 2,882 & 0,851 \\
\hline & Dağıtımsal Adalet & 2,573 & 1,087 \\
\hline & & & \\
\hline & Etkileşimsel Adalet & 3,308 & 1,125 \\
\hline & Örgütsel Adalet Algısı & 2,996 & 0,841 \\
\hline
\end{tabular}

Tablo 7: Korelasyon Tablosu ve Ortalamalar

\begin{tabular}{|c|c|c|c|c|c|}
\hline & 1 & 2 & 3 & Ort. & S.S. \\
\hline İşlevsel Adalet (1) & & & & 3,00 & 0,86 \\
\hline Dağıtım Adaleti (2) & $0,467^{* *}$ & & & 2,72 & 1,09 \\
\hline Etkileșimsel Adalet (3) & $0,540^{* *}$ & $0,384^{* *}$ & & 3,33 & 1,05 \\
\hline Örgütsel Adalet Algısı & $0,825^{* *}$ & $0,681^{* *}$ & $0,872^{* *}$ & 3,08 & 0,80 \\
\hline
\end{tabular}


Örgütsel adalet algısı ve alt boyutları arasındaki ilişkiler ve aritmetik ortalamaları Tablo 7'de görülmektedir. Buna göre örgütsel adalet algısı ve bütün alt boyutlar birbirleri ile pozitif yönlü ilişki göstermektedir. Örgütsel adalet algısı ve alt boyutlarının ortalamalarına bakıldığında ise örgütsel adalet algısı, işlemsel adalet boyutu ve etkileşimsel adalet boyutu ortalama değere sahipken etkileşimsel adalet boyutu düşük olduğu saptanmıştır.
Tablo 8'de katılımcıların istihdam şekillerine göre örgütsel adalet algılarına yönelik yapılan ANOVA analizi sonuçları yer almaktadır. Buna göre katılımcıların örgütsel adalet algılarında istatistiki olarak anlamlı farklılık bulunmaktadır. $\mathrm{Bu}$ farklılığın hangi gruplardan kaynaklandığını belirlemek amaciyla yapılan Post-Hoc analizine göre farklılık devlet memurları ile sözleşmeli çalışanlar (p: 0,027) ve devlet memurları ile taşeron işçiler (p: 0,002) arasındaki farklılıktan

Tablo S: İstihdam Şekillerine Göre Örgütsel Adalet Algıs1 Farklllik Tablosu

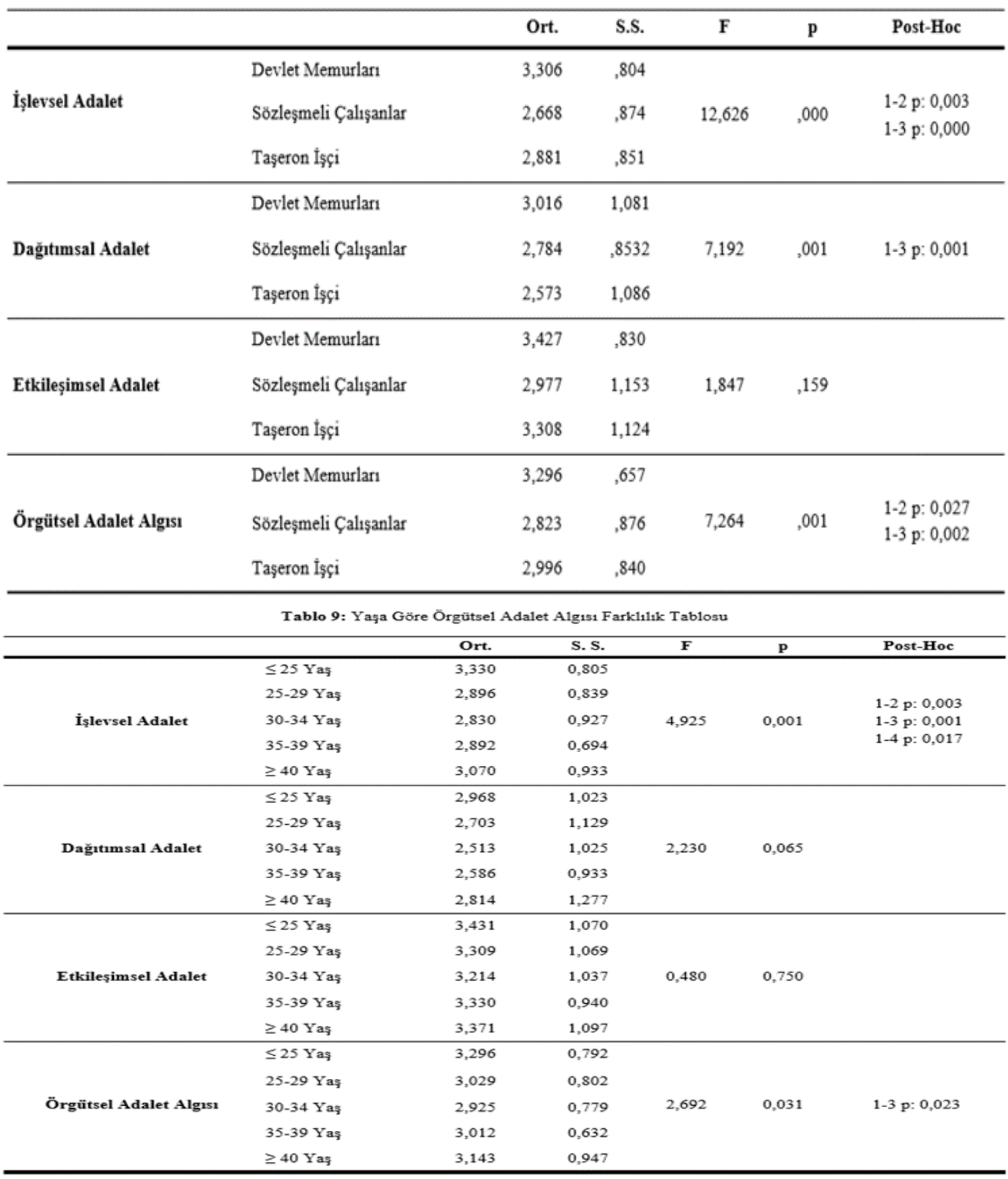


kaynaklanmaktadır. Ortalamalara bakıldığında devlet memurlarının örgütsel adalet algıları sözleşmeli çalışanlar ve taşeron işçilere oranla daha olumlu görülmektedir. Genel örgütsel adalet algısının yanı sıra işlemsel adalet ve dağıtımsal adalet boyutlarında da anlamlı farklılıklar görülmektedir.

$\mathrm{Bu}$ boyutlarda da devlet memurlarının algıları sözleşmeli çalışanlar ve taşeron işçilere oranla daha olumlu görülmektedir. Etkileşimsel adalet boyutunda ise istihdam şekillerine göre bir farklılık görülmemektedir.

Tablo 9'da katılımcıların yaş gruplarına göre örgütsel adalet algılarında farklılık olup olmadığını test etmek amaciyla yapilan ANOVA analizi sonuçları yer almaktadır. Buna göre katılımcıların yaşlarına göre örgütsel adalet algıları istatistiki olarak anlamlı şekilde farklılaşmaktadır. $\mathrm{Bu}$ farklılığın kaynaklandığı grubu belirlemek amacıyla yapılan Post-Hoc analizine göre farklılık 25 yaş ve alt1 grup ile 30-34 yaş aras1 gruptan (p: 0,023) kaynaklanmaktadır. 30-34 yaş gurubunda örgütsel adalet algılaması daha düşük bulunmuştur. Yaşa göre anlamlı farklılığın bulunduğu bir diğer değişken ise işlemsel adalet boyutudur. Bu boyutta 25 yaş ve altı grup ile 25-29 yaş arası, 30-34 yaş arası ve 35-39 yaş arası gruplar arasında anlamlı farklılık bulunmaktadır. 25 yaş ve altı grubunda bulunan katılımcıların diğer gruplara oranla hem örgütsel adalet algıları hem de işlemsel adalet algıları daha olumludur. Diğer boyutlarda istatistiksel açıdan anlamlı farklılık olmamasına rağmen 25 yaş ve altı grup diğer yaş gruplarına göre daha olumlu bir ortalamaya sahiptir.

Katılımcıların eğitim durumlarına göre örgütsel adalet algılarında anlamlı farklılık olup olmadığına dair yapılan ANOVA analizi sonuçlarına göre (Tablo 10); dağıtımsal adalet boyutu dişındaki boyutlarının ve örgütsel adalet algısının eğitim durumuna göre anlamlı farklılık göstermektedir. $\mathrm{Bu}$ farklılık örgütsel adalet algısı için ilköğretim mezunları ile lise, ön lisans ve lisans mezunları arasındaki farklılıktan; işlemsel adalet boyutu için ilköğretim mezunları ile ön lisans, lisans ve lisansüstü mezunları arasındaki farklılıktan; etkileşimsel adalet boyutu için ilköğretim mezunları ile lise, ön lisans ve lisans mezunları arasındaki farklılıktan kaynaklanmaktadır. Genel olarak lisans ve ön lisans mezunlarının ilköğretim mezunlarına oranla algıları daha olumlu olduğu saptanmıştır.

Tablo 10: Eğitim Durumuna Gōre Örgütsel Adalet Algısı Farklalık: Tablosu

\begin{tabular}{|c|c|c|c|c|c|c|}
\hline & & Ort. & S.S. & $\mathbf{F}$ & $\mathbf{p}$ & Post-Hoc \\
\hline \multirow{5}{*}{ İşlevsel Adalet } & Illk:öğretim & 2,476 & 0,836 & & & \multirow{5}{*}{$\begin{array}{l}1-3 \text { p: } 0,011 \\
1-4 \text { p: } 0,005 \\
1-5 \text { p: } 0,038\end{array}$} \\
\hline & Lise & 2,917 & 0,857 & & & \\
\hline & Ōn lisans & 3,063 & 0,835 & 3,749 & 0,005 & \\
\hline & Lisans & 3,115 & 0,860 & & & \\
\hline & Lisansüstü & 3,169 & 0,850 & & & \\
\hline \multirow{5}{*}{ Dağıtımsal Adalet } & Îlkōğretim & 2,296 & 1,002 & \multirow{5}{*}{2,405} & \multirow{5}{*}{0,049} & \\
\hline & Lise & 2,574 & 1,119 & & & \\
\hline & Ōn lisans & 2,786 & 1,037 & & & \\
\hline & Lisans & 2,882 & 1,097 & & & \\
\hline & Lisansüstü & 2,852 & 1,138 & & & \\
\hline \multirow{5}{*}{ Etkileşimsel Adalet } & Illkōgretim & 2,597 & 1,185 & & & \multirow{5}{*}{$\begin{array}{l}1-2 \text { p: } 0,003 \\
1-3 \text { p: } 0,001 \\
1-4 \text { p: } 0,008\end{array}$} \\
\hline & Lise & 3,399 & 1,037 & & & \\
\hline & Ön lisans & 3,441 & 1,092 & 4,075 & 0,003 & \\
\hline & Lisans & 3,339 & 0,901 & & & \\
\hline & Lisansüstü & 3,153 & 1,053 & & & \\
\hline \multirow{5}{*}{ Örgütsel Adalet Algısı } & Illkögretim & 2,489 & 0,855 & & & \multirow{5}{*}{$\begin{array}{l}1-2 \text { p: } 0,009 \\
1-3 \text { p: } 0,001 \\
1-4 \text { p: } 0,001\end{array}$} \\
\hline & Lise & 3,048 & 0,811 & & & \\
\hline & Ön lisans & 3,164 & 0,825 & 4,482 & 0,001 & \\
\hline & Lisans & 3,160 & 0,708 & & & \\
\hline & Lisansüstü & 3,096 & 0,758 & & & \\
\hline
\end{tabular}


Tablo 11: Gelir Durumuna Göre Örgütsel Adalet Alg1s1 Farklilik Tablosu

\begin{tabular}{|c|c|c|c|c|c|c|}
\hline & TL & Ort. & S.S. & $\mathrm{F}$ & $\mathrm{p}$ & Post-Hoc \\
\hline \multirow{4}{*}{ İşlevsel Adalet } & Asgari Ücret & 2,699 & 0,898 & \multirow{4}{*}{9,338} & \multirow{4}{*}{0,000} & \multirow{4}{*}{$\begin{array}{l}1-3 \mathrm{p}: 0,017 \\
1-4 \mathrm{p}: 0,000 \\
2 \cdot \mathrm{p}: 0,001\end{array}$} \\
\hline & $1500-1999$ & 2,804 & 0,846 & & & \\
\hline & 2000-2999 & 3,071 & 0,780 & & & \\
\hline & $\geq 3000$ & 3,287 & 0,779 & & & \\
\hline \multirow{4}{*}{ Dağıtımsal Adalet } & Asgari Ücret & 2,203 & 1,041 & \multirow{4}{*}{13,955} & \multirow{4}{*}{0,000} & \multirow{4}{*}{$\begin{array}{l}1-3 \mathrm{p}: 0,000 \\
1-4 \mathrm{p}: 0,000 \\
2-3 \mathrm{p}: 0,002 \\
2-4 \mathrm{p}: 0,001\end{array}$} \\
\hline & $1500-1999$ & 2,440 & 1,053 & & & \\
\hline & $2000-2999$ & 3,011 & 0,993 & & & \\
\hline & $\geq 3000$ & 3,010 & 1,028 & & & \\
\hline \multirow{4}{*}{ Etkileşimsel Adalet } & Asgari Ücret & 3,035 & 1,189 & \multirow{4}{*}{4,187} & \multirow{4}{*}{0,006} & \multirow{4}{*}{$1-3 p: 0,003$} \\
\hline & $1500-1999$ & 3,251 & 1,211 & & & \\
\hline & $2000-2999$ & 3,587 & 0,957 & & & \\
\hline & $\geq 3000$ & 3,362 & 0,797 & & & \\
\hline \multirow{5}{*}{ Örgütsel Adalet Algısı } & Asgari Ücret & 2,736 & 0,851 & \multirow{5}{*}{10,226} & \multirow{5}{*}{0,000} & \multirow{5}{*}{$\begin{array}{l}1-3 p: 0,000 \\
1-4 p: 0,000 \\
2-3 p: 0,014 \\
2-4 p: 0,017\end{array}$} \\
\hline & $1500-1999$ & 2,916 & 0,866 & & & \\
\hline & $2000-2999$ & 3,276 & 0,735 & & & \\
\hline & $\geq 3000$ & 3,260 & 0,660 & & & \\
\hline & & & & & & \\
\hline
\end{tabular}

Tablo 11'de çalışanların gelir durumlarının örgütsel adalet algılarında farklılık oluşturup oluşturmadığını test etmek amacıyla yapılan ANOVA analizi sonuçları yer almaktadır. Bu sonuçlara göre çalışanların örgütsel adalet algılarında ve alt boyutlarında gelir durumu anlamlı farklılığa sebep olmaktadır. Örgütsel adalet algısı ve dağıtımsal adalet boyutu için farklılık asgari ücret alan çalışanlar ile 2000-2999 ve 3000 TL üzeri alan çalışanlar arasındaki farklılıktan ve 1500-1999 TL arası alan çalışanlar ile $2000-2999$ ve 3000 TL üzeri alan çalışanlar arasındaki farklılıktan kaynaklanmaktadır. İşlevsel adalet boyutu için farklılık asgari ücret alan çalışanlar ile 2000-2999 ve 3000 TL üzeri alan çalışanlar arasındaki farklılıktan ve 1500-1999 TL arası alan çalışanlar ile 2000-2999 TL arası alan çalışanlar arasındaki farklılıktan kaynaklanmaktadır. Etkileşimsel adalet boyutundaki farklılık ise asgari ücret alan çalışanlar ile 2000-2999 TL arasında alan çalışanlar arasındaki farklılıktan kaynaklanmaktadır. Genel olarak bakıldığı zaman asgari ücret alan çalışanların örgütsel adalet algıları 2000 TL ve üzerinde gelirleri olan bireylere oranla oldukça düşüktür.

Tablo 12'de idari görevi olan çalışanların örgütsel adalet algıları ile idari görevi olmayan çalışanların örgütsel adalet algıları arasında anlamlı farklılık olup olmadığını belirlemek amaciyla yapılan bağımsız örneklemlerde $t$ testi sonuçları yer almaktadır. Bu sonuçlara göre idari görevin olup olmaması durumu örgütsel adalet algisında, işlemsel adalet ve dağıtımsal adalet boyutunda anlamlı farklılık oluşturmaktadır. İdari görevi olan çalışanların algıları olmayan çalışanlara göre daha yüksek olduğu saptanmıştır.

Bunların yanı sıra katılımcıların cinsiyetleri, medeni durumları ve kurumda çalışma süreleri örgütsel adalet algısında ve alt boyutlarında bir farklılığa sebep olmamaktadır. Tüm bulgular neticesinde araştırma kapsamında kurulan h1, h2, h3, h4 ve h5 hipotezleri kabul edilmiş ve $\mathrm{h} 6, \mathrm{~h} 7$ ve $\mathrm{h} 8$ hipotezleri ret edilmiştir (Tablo 13).

\section{TARTIŞMA VE SONUÇ}

$\mathrm{Bu}$ çalışmada hastane çalışanlarının istihdam şekillerine göre örgütsel adalet algılamalarının farklılık gösterip göstermediği amaçlanmıştır.

Çalışmanın sonuçlarına göre devlet memurlarının örgütsel adalet algıs1 ortalamaları 3,29 olup, işlemsel adalet algısı ortalamaları 3,30, dağıtımsal 
Tablo 12: İari Görev Olup Olmamasma Göre Örgütsel Adalet Algısı Farklulık Tablosu

\begin{tabular}{|c|c|c|c|c|c|}
\hline İdari Görev & & Ort. & S.H & $t$ & p \\
\hline \multirow{2}{*}{ İ̇sersel Adalet } & Evet & 3,209 & 0,101 & \multirow{2}{*}{2,051} & \multirow{2}{*}{0,044} \\
\hline & Hayır & 2,979 & 0,047 & & \\
\hline \multirow{2}{*}{ Dağttmmsal Adalet } & Evet & 3,035 & 0,143 & \multirow{2}{*}{2,175} & \multirow{2}{*}{0,030} \\
\hline & Hayır & 2,680 & 0,058 & & \\
\hline \multirow{2}{*}{ Etkileşimsel Adalet } & Evet & 3,415 & 0,142 & \multirow{2}{*}{0,722} & \multirow{2}{*}{0,471} \\
\hline & Hayır & 3,300 & 0,057 & & \\
\hline \multirow{2}{*}{ Örgütsel Adalet Algsıı } & Evet & 3,259 & 0,098 & \multirow{2}{*}{1,708} & \multirow{2}{*}{0,088} \\
\hline & Hayır & 3,052 & 0,044 & & \\
\hline
\end{tabular}

Tablo 13: Hipotez Sonuç Tablosu

\begin{tabular}{cc}
\hline Hipotezler & Sonuç \\
\hline Hipotez 1: İstihdam şekline göre örgütsel adalet algısnda anlamlı farklllk vardır. & Kabul \\
\hline
\end{tabular}

Hipotez 2: Yaş örgütsel adalet algısında anlamlı farklılık oluşturmaktadır.

Hipotez 3: Eğitim durumu örgütsel adalet algısında anlamlı farklılık olușturmaktadır.

Hipotez 4: Gelir durumu örgütsel adalet algısında anlamlı farklılık olușturmaktadır.

Kabul

Hipotez 5: İdari görevi olup olmaması örgütsel adalet algısında anlamlı farklllık oluşturmaktadır.

Kabul

Hipotez 6: Cinsiyet örgütsel adalet algısında anlamlı farklılık olușturmaktadır.

Hipotez 7: Medeni durum örgütsel adalet algısında anlamlı farklılık olușturmaktadır.

Ret

Hipotez 8: Çalıșma süresi örgütsel adalet algısında anlamlı farklılık oluşturmaktadır.

Ret

adalet algısı ortalamaları 3,016 ve etkileşimsel adalet alg1S1 ortalamalar1 3,427'dir. Devler memurlarının örgütsel adalet algısı ve alt boyutlara ilişkin alg1 ortalamaları genel olarak orta seviyededir. Bu ortalamalar sözleşmeli personel ve taşeron işçiler için ise genel olarak orta seviyenin altında görülmektedir. Sözleşmeli çalışanların örgütsel adalet alg1s1 ortalamaları 2,823 olup, işlemsel adalet algısı ortalamaları 2,669, dağıtımsal adalet algısı ortalamaları 2,784 ve etkileşimsel adalet algısı ortalamaları 2,977'dir. Taşeron işçilerin ise örgütsel adalet algısı ortalamaları 2,996, işlemsel adalet algısı ortalamaları 2,882, dağıtımsal adalet algısı ortalamaları 2,573 ve etkileşimsel adalet algısı ortalamaları 3,308'dir. Buna göre özellikle sözleşmeli personelin örgütsel adalet algılaması en düşük, taşeron işçilerde düşük, devlet memurlarında ise en yüksek olduğu saptanmıştır.

Memurlar ile sözleşmeli çalışanlar ve taşeron işçilerin örgütsel adalet algıları arasında bir farklılık olup olmadığına ilişkin yapılan ANOVA testi sonuçları ise çalışanların istihdam biçimlerinin örgütsel adalet algısında anlamlı bir farklılık oluşturduğunu ortaya koymaktadır. Bulunan bu farklılık devlet memurları ile sözleşmeli personel arasındaki farklılıktan ve devlet memurları ile taşeron işçiler arasındaki farklılıktan kaynaklanmaktadır. Örgütsel adalet algısının alt boyutu olan işlemsel adalet ve dağıtımsal adalet boyutlarında da istihdam biçimi anlamlı farklılık oluştururken, etkileşimsel adalet boyutunda 
memurlar ile sözleşmeli çalışanlar ve taşeron işçi arasında anlamlı bir farklılık bulunmamaktadır.

Çalışmanın diğer t-testi ve ANOVA testi sonuçlarına göre ise çalışanların yaşları, eğitim durumları, aylık ortalama gelirleri ve idari görevleri olup olmaması örgütsel adalet algılarında anlamlı farklılık oluştururken cinsiyet medeni durum ve çalışma süreleri anlamlı bir farklılık oluşturmamaktadır. Bu sonuçlar yaş için Cihangiroğlu, Şahin \& Naktiyok (2010: 79)'nın çalışmasıyla, ortalama gelir için Keklik ve Coşkun Us (2013: 154)'un çalışmasıyla, cinsiyet için Durmuş (2015: 65)'un çalışmasıyla, medeni durum için Özkılıçcı (2011: 113)'nın çalışmasıyla, çalışma süresi için Baş ve Şentürk (2011: 42)'ün çalışmasıyla benzerlik gösterirken; yaş ve eğitim durumu için Durmuş (2015: 66)'un, ortalama gelir için Özkılıçcı (2011: 118)'nın, cinsiyet ve medeni durum için Keklik ve Coşkun Us (2013: 151)'un, idari görev olup olmaması bakımından ise Özkılıçcı (2011: 115)'nın çalışmalarıyla farklılık göstermektedir.

Çalışmanın sonuçları irdelendiği zaman; çalışanların istihdam biçimlerinin örgütsel adalet algılarını etkilemesi ve memurların örgütsel adalet algılarının sözleşmeli çalışanlar ile taşeron işçilere oranla daha yüksek olması yöneticiler ve politika yapıcılar açısından önemli bir sonuç olarak görülmektedir. Emek yoğun hizmet sunan sağlık kuruluşlarının kalite ve performans hedeflerine ulaşması en alt düzeyden en üst düzeye kadar bütün çalışanların tamamının göstereceği performans ve özveriye bağlıdır. Bireyler, eğer örgütlerinde adaletsizlikler yapıldığını ilişkin algıları oluşursa, bu onların pek çok davranışına etkide bulunabilir (Özdevecioğlu, 2003: 90). Örneğin örgütel adalet algısı çalışanların iş tatminini pozitif yönde etkilemekte (Keklik ve Coşkun Us, 2013: 143), duygusal ve normatif bağlılığını pozitif yönde etkilemekte (Iş1k vd., 2012: 254), sistemden memnuniyetini pozitif yönde etkilemekte (Tan, 2009: 194), çalışan motivasyonu ve bireysel performansı pozitif yönde etkilemekte (Sökmen, Bilsel \& Erbil, 2013: 55), örgütsel bağlılık ve örgütsel vatandaşlik ile pozitif yönlü ilişki içerisinde (Polat \& Celep, 2008: 323), tükenmişlik ile ise negatif yönlü ilişki içerisindedir (Balaban \& Konyalı, 2016: 197). Örgütsel adalet algısının literatürde farklı sektörlerde yapılan bu çalışmalar tarafından ortaya konulan öneminin sağlık işletmelerindeki karşılığ 1 ise yadsınamaz. $\mathrm{Bu}$ nedenle sağlık kurumları yöneticilerinin ve sağlık politika belirleyicilerinin istihdam biçimlerinin örgütsel adalet algısında farklılık oluşturduğunun bilincinde olması ve bu farklılığın giderilmesine yönelik çalışmalar yapması sağlık kurumları açısından büyük önem arz etmektedir.

\section{KAYNAKÇA}

Adams, J. S. (1965). Inequity in Social Exchange. Advances in Experimental Social Psychology, 2, 267299.

Akbolat, M. \& Işık, O. (2008). Sağlık Çalışanlarının Tükenmişlik Düzeyleri: Bir Kamu Hastanesi Örneği. Hacettepe Sağllk İdaresi Dergisi, 11(2), 229-254.

Akdağ, R. (2007), Nereden Nereye Türkiye Sağlıkta Dönüşüm Programı Kasım 2002- Haziran 2007, T. C. Sağlık Bakanlığı Yayın No:713, Ankara.

Alper Ay F., G. Demirel \& N. Erbaş, (2017). Örgütsel Adaletin Sanal Kaytarma Üzerindeki Etkisi: Sağlik Çalışanlarına Yönelik Bir Araştırma, Research Journal Of Business And Management, 4(3), 400-409.

Aykanat, Z. \& Yıldırım, A. (2012), Etik Liderlik ve Örgütsel Adalet İlişkisi: Teorik ve Uygulamalı Bir Araştırma. Fırat Üniversitesi Sosyal Bilimler Dergisi, 22(2), 260-274.

Balaban, Ö. \& Konyalı, H. (2016). Kamu Çalışanlarının Tükenmişlik Düzeyleri ile Örgütsel Adalet Algıları Arasındaki İlişkinin İncelenmesi: Sakarya Sgk Örneği. Siyaset, Ekonomi ve Yönetim Araştırmaları Dergisi, 4(1): 189-207.

Barling, J. \& Phillips, M. (1993). Interactional, Formal, and Distributive Justice in the Workplace: An Exploratory Study. The Journal of Psychology, 127(6), 649-656.

Baş, G. \& Şentürk, C. (2011). İlköğretim okulu öğretmenlerinin örgütsel adalet, örgütsel vatandaşl1k ve örgütsel güven algıları. Kuram ve Uygulamada Ĕ̈itim Yönetimi Dergisi, 17(1), 29-62.

Baş, T., Ünal, Ö., Amarat, M., \& Sağlık, D. (2017). Hemşirelerde İş Tatmininin Motivasyon Düzeyine Etkisi. Örgütsel Davranış Araştırmaları Dergisi, 2(2), 20-39.

Başar, U. (2011). Örgütsel Adalet Alglsl, Örgütsel Özdeşleşme ve İş Tatmini Arasindaki Illişkilere Yönelik Görgül Bir Araştırma (Yayınlanmamış Yüksek Lisans Tezi). Kara Harp Okulu, Ankara.

Batchelder, J. S. \& Alexander, R. C. (2009). Effects of Personnel Policy on the Public Administration Paradigm Shift: From Merit to Neo-Managerial. Journal of Social Science, 21(2), 153-159.

Büyükyılmaz O. \& Alper Ay, F. (2017). Etik Liderliğin Örgütsel Vatandaşlık Davranışına Etkisinde Örgütsel Adaletin Arac1lık Rolü. Hitit Üniversitesi Sosyal Bilimler Enstitüsü Dergisi, 10(1), 209-233.

Çetin, F., Basım, H. N. \& Karataş, M. (2011). Çalışanların Problem Çözme Becerilerinde Örgütsel Adalet Algısı Ve İş Tatmininin Rolü. Yönetim Ve Ekonomi, 18(1), 71-85. 
Cihangiroğlu, N. (2011). Askeri Doktorların Örgütsel Adalet Algıları İle Örgütsel Bağlılıkları Arasındaki İlişkinin Analizi. Gülhane Tip Dergisi, 53(1), 9-16.

Cihangiroğlu, N., Şahin, B. \& Naktiyok, A. (2010). Hekimlerin Örgütsel Adalet Algıları Üzerine Bir Araştırma. Uluslararası Yönetim İktisat ve İşletme Dergisi, 6(12), 67-82.

Cohen-Charash, Y. \& Spector, P.E. (2001). The Role of Justice in Organizations: A Meta-Analysis. Organizational Behavior and Human Decision Process, 86(2), 278-321.

Colquitt, J. A. (2001). On The Dimensionality of Organizational Justice: A Construct Validation of a Measure. Journal of Applied Psychology, 86(3), 386400 .

Conway, N. \& Briner, R. B. (2002). Full-time versus parttime employees: Understanding the links between work status, the psychological contract, and attitudes. Journal of Vocational Behavior, 61(2), 279-301.

Durmuş, R. (2015). Örgütsel Adalet Ve Tükenmişlik Arasındaki Etkileşimin Değerlendirilmesine Yönelik Bir Araştırma- Eskişehir'de Bir Kamu Hastanesi Örneği (Yayınlanmamış Yüksek Lisans Tezi). Toros Üniversitesi, Sosyal Bilimler Enstitüsü, Mersin.

Eberhardt, B. J. \& Shani, A. B. (1984). The effects of full-time versus part-time employment status on attitudes toward specific organizational characteristics and overall job satisfaction. Academy of Management Journal, 27(4), 893-900.

İçerli, L. (2010). Örgütsel Adalet: Kuramsal Bir Yaklaşım. Girişimcilik ve Kalkınma Dergisi, 5(1):6792.

Işık, O., Uğurluoğlu, Ö. \& Akbolat, M. (2012). Sağlık Kuruluşlarında Örgütsel Adalet Algılarının Örgütsel Bağlılığa Etkisi. Doğuş Üniversitesi Dergisi, 13(2): 254-265.

İyigün, N. Ö. (2012), Örgütsel Adalet: Kuramsal Bir Yaklaşım. İstanbul Ticaret Üniversitesi Sosyal Bilimler Dergisi, 11(21), 49-64.

Kalay, F., Arslan, H. \& Oflas, Ş. (2013). Kadrolu ve 4/B Sözleşmeli Yardımcı Sağlık Personellerinin İş Doyumlarının Karşılaştırılması. Selçuk Üniversitesi Sosyal Bilimler Enstitüsü Dergisi, (29), 111-121.

Kaplan, M. \& Öğüt, A. (2012). Algılanan Örgütsel Adalet İle Sanal Kaytarma Arasındaki İlişkinin Analizi: Hastane Çalışanları Örneği. Dokuz Eylül Üniversitesi İsletme Fakültesi Dergisi, 13(1), 1-13.

Karahan, A. (2008). Çalışma Ortamındaki Statü Farklılıklarının Örgütsel Bağl1lığa Etkisi. Sosyal Bilimler Dergisi, 10(3), 231-246.
Keklik, B. \& Coşkun Us, N. (2013). Örgütsel Adalet Algılamalarının İş Tatminine Etkisi: Hastane Çalışanları Üzerinde Bir Araştırma. Süleyman Demirel Üniversitesi İktisadi ve İdari Bilimler Fakültesi Dergisi, 18(2), 143-161.

Meydan, C.H. \& Şeşen, H. (2015). Yapısal Eşitlik Modellemesi Amos Uygulamaları. 2. Baskı. Ankara: Detay Yayınc1lik.

Miller, H.E. \& Terborg, J.R. (1978). Part-time and fulltime workers: Exploratory data and conceptual analysis. Unpublished paper. University of Illinois.

Nowakowski, J. M. \& Donald E. C. (2005). Organizational Justice: Looking Back, Looking Forward. International Journal of Conflict Management, 16(1), 4-29.

Omar, M. K. (2010). Work Status Congruence, WorkRelated Attitudes, And Satisfaction Towards WorkLife Balance. International Review of Business Research Papers, 6(1), 145-156.

Özdevecioğlu, M. (2003). Algılanan Örgütsel Adaletin Bireylerarası Saldırgan Davranışlar Üzerindeki Etkilerinin Belirlenmesine Yönelik Bir Araştırma. Erciyes Üniversitesi İ̈BF Dergisi, 21, 77-96.

Özen, Y. \& Gül, A. (2007). Sosyal ve Eğitim Bilimleri Araştirmalarinda Evren-Örneklem Sorunu. Atatürk Üniversitesi Kazım Karabekir Eğitim Fakültesi Dergisi, 15, 394-422.

Özkılıçc1, G. (2011). Örgütsel Adalet Algısı İle Örgütsel İletişim Arasındaki İlişkinin Belirlenmesine Yönelik Bir Araştırma (Yayınlanmamış Yüksek Lisans Tezi). Marmara Üniversitesi, Sosyal Bilimler Enstitüsü, İstanbul.

Özmen, O. N., Arbak, Y. \& Özer, P. S. (2007). Adalete Verilen Değerin Adalet Algıları Üzerindeki Etkisinin Sorgulanmasına İlişkin Bir Araştırma. Ege Akademik Bakış Dergisi, 7(1), 19-35.

Polat, S. \& Celep, C. (2008). Ortaöğretim Öğretmenlerinin Örgütsel Adalet, Örgütsel Güven, Örgütsel Vatandaşlık Davranışlarına İlişkin Algıları. Kuram ve Uygulamada Eğitim Yönetimi Dergisi, 14(2), 307-331.

Sağlık Bakanlığı (2015). Sağlık İstatistiği Yıllığı 2015. Sağlık Araştırmaları Genel Müdürlüğü. Ankara. Sentez Matbaacılık ve Yayıncılık.

Sağlık Bakanlığı (2016). Sağlık İstatistiği Yıllığı 2015. http://www.metaveri.saglik.gov.tr/book/SIY_2016_H aber_Bulteni.pdf. Erişim tarihi: 6/10/2017.

Savgun Doğruöz, S. (2009). Kadrolu ve Sözleşmeli Öğretmenlerin Örgütsel Bağlllık Düzeylerinin Karşılaştırılması (Yayımlanmamış Yüksek Lisans 
Tezi). Ondokuzmayıs Üniversitesi Sosyal Bilimler Enstitüsü, Samsun.

Sayan, İ. Ö. \& Küçük, A. (2012). Türkiye'de Kamu Personeli İstihdamında Dönüşüm: Sağlık Bakanlığ Örneği. Ankara Üniversitesi SBF Dergisi, 67(01), 171-203.

Sökmen, A., Bilsel, M. A. \& Erbil, C. (2013). Örgütsel Adaletin Çalışan Motivasyonu Ve Performansı Üzerindeki Etkisi: Bankacılık Sektöründe Bir Araştırma. İktisadi Ve İdari Bilimler Fakültesi Dergisi, 15(1), 43-62.

Tan, Ö. (2009). Performans Değerlendirme Sistemine İlişkin Örgütsel Adalet Algısının Sistemden Duyulan Memnuniyet Üzerindeki Etkisini Belirlemeye Yönelik Bir Araştırma (Yayınlanmamış Yüksek Lisans Tezi). Marmara Üniversitesi, Sosyal Bilimler Enstitüsü, İstanbul.

Tezcan, C. (2008). Yapısal Eşitlik Modelleri (Yayımlanmamış Yüksek Lisans Tezi). Hacettepe Üniversitesi, Sosyal Bilimler Enstitüsü, Ankara.

Thorsteinson, T. J. (2003). Job attitudes of part-time vs. full-time workers: a meta-analytic review. Journal of Occupational and Organizational Psychology, 76(2), 151-177.

Tutar, H. (2007). Erzurum'da Devlet Ve Özel Hastanelerde Çalışan Sağlık Personelinin İşlem Adaleti, İş Tatmini ve Duygusal Bağlılık Durumlarının İncelenmesi. Süleyman Demirel Üniversitesi İktisadi ve İdari Bilimler Fakültesi Dergisi, 12(3), 97-120.

Ünalan, D., Çetinkaya, F., Özyurt, Ö. \& Kayabaşı, A. (2006). Bir Üniversite Hastanesinde Çalışan Sekreterlerde İş Memnuniyeti. Hacettepe Sağllk Idaresi Dergisi, 9(1).1-18.

Yalçın, B. (2011). Kamu sektöründe sözleşmeli personel istihdamı: Akdeniz Üniversitesi örneği (Doktora tezi). SDÜ Sosyal Bilimler Enstitüsü, Isparta.

Yıldırım, F. (2007). İş Doyumu İle Örgütsel Adalet İlişkisi. Ankara Üniversitesi SBF Dergisi, 62(01), 253-278. 